\title{
Freshman Linked Cohort Classes In The Study Of Business: Results Of Performance And Graduation In Business
}

Mark F. Levine, (Email: mlevine@csuchico.edu), California State University, Chico Paul W. Guy, (Email: pguy@csuchico.edu), California State University, Chico

\begin{abstract}
The paper presents the results of a study designed to measure the efficacy of using cohort linked freshmen courses in preparing students for the study of business. Specifically, an experimental group of students were enrolled in three linked freshmen courses each oriented toward global business: 1) freshmen composition, 2) small group communications, and 3) introduction to global business. The control group of students was enrolled in the introduction to global business course. However, they independently enrolled in any other non-business focused freshmen courses to fill out their schedules.
\end{abstract}

\section{INTRODUCTION}



ubstantial changes in higher education have developed in the last decade as reliance on technology has increased, student demographics have become more diverse to reflect an emphasis on life-long learning and continuing education, and institutions have strove to become student centered in an era of customer focused relationships. One result of these rapid changes has been an increased awareness of the need to build learning communities to promote student learning and retention.

The formation and maintenance of learning communities helps universities provide an educational experience rich in faculty and peer support networks as well as creating an opportunity for students to fully participate in directing their own learning experience (Kellogg, 1999). "A learning community is any one of a variety of curricular structures that link together several existing courses - or actually restructure the curriculum material entirely - so that students have opportunities for deeper understanding and integration of the material they are learning, and more interaction with one another and their teachers as fellow participants in the learning enterprise" (Gabelnick, MacGregor, Matthews, and Smith, 1990, p. 19). Kellogg (1999) identifies five major learning community models: Linked Courses, Learning Clusters, Freshmen Interest Groups, Federated Learning Communities, and Coordinated Studies. The focus of the present study will be on the efficacy of freshman linked cohort classes in the study of business at California State University Chico.

In an early study of London medical students, Abercrombie (1960) showed that successful medical students intuit the importance of feedback, assimilation, accommodation, and other social cognitive aspects of collaboration. Other research indicates students seek out experiences with peers that provide opportunities for learning goal setting, negotiation of authority, personal responsibility, persistence, inductive and deductive approaches to learning, creative and logical application of new information, and interdependence with students of different backgrounds (Horn, 1997). Linked courses allow college instructors to actively provide their students with these opportunities for peer support and self-directed learning by creating learning communities with similar interests. In this way, educators can build on the best learning methods already established by successful students. 
The most common type of learning community is where two or more courses are linked together by a common theme. The University of Arkansas at Little Rock (UALR) implemented this linked courses method to help students stay in school past the critical first semester when many of them tend to leave (Thompson, 1998). Assessment indicated a positive result on UALR's first attempt at a learning community involving 25 linked cohort students enrolled in anthropology, rhetoric and writing, and speech courses. On an attitude survey, $88 \%$ of learning community students agreed that it is important to recognize the connections among other course content, and $84 \%$ maintained that the learning community had helped them to see those connections (Thompson, 1998).

The desire to help students recognize the relevance of their education and the connections that exist across discipline boundaries is a driving force in linking courses (Fitch and Kirby, 2000). Fitch and Kirby describe this as the "“content-skill' binary" and show the importance of linking content courses such as American National Government with skill courses such as English Composition. This interdisciplinary linking of courses allows students to think about issues from the different perspectives of the communities in which they are involved. For instance, writing instruction that occurs outside the English Department and in a specific discipline attempts to teach students how to talk and write about that particular body of knowledge and, therefore, access that community (O'Connor and Ruchala, 1998). This concept is similar to the present study in which an Introductory Business Administration course was linked to both a freshman English course and an Oral Communications course. In fact, it is imperative that business students gain the ability to consider issues from a variety of community perspectives because business applications are so broad that graduates can find themselves working in literally any field (O'Connor and Ruchala, 1998).

Another style of cohort courses involves linking a content course with a first-year seminar course for entering freshmen. Indiana University Purdue University Indianapolis (IUPUI) has used this method and found that in all semesters except the first one, seminar participants were retained by a significantly higher percentage. Data collected on grades at the end of the fall 1997 semester showed that seminar participants also earned a higher percentage of high grades than non-participants who were also new to IUPUI (Dick, 1998).

Studies have also pointed out other academic and social benefits of creating learning communities through linked courses. For instance, linked students as part of an organized learning community program achieved increased numbers of completed credits and somewhat higher grade point averages (GPA) (Eanes and Tutchings, 1990; LuvaasBriggs, 1984) than their unlinked counterparts. In other studies, linked students were found to have increased GPA and greater retention rates (Sorensen, 1988; Tinto, Goodsell-Love, and Russo, 1993). Additional research found linkages associated with better performance on a content course exam and self-expressed confidence in using skills from the program (Gammill, Hansen, and Tinkler, 1992); and increased open-mindedness and confidence in composition skills (Spear, Liff, Hunt, and Jarvis, 1990). Other positive finding comparing linked with unlinked students included increased interaction between students and faculty and among students as well as increased student intellectual development, retention, and motivation (Smith, 1991); and enhanced understanding of the relevance of and relationships among different subjects (Dunn, 1993; Wishnet, 1991). Most authors concur that the most important benefit of the linked-course model is the establishment of a social and academic support system, allowing students to get to know one another and, in some instances, their instructors, better than they might have otherwise (Tinto \& Goodsell, 1993; Tinto, Goodsell-Love, and Russo, 1993).

George Mason University Linked states on its web-site that "linked courses will help you to find a community of people who know who you are and who care about what you think. They will also help you make connections between important ideas across different fields of study. Linked courses will help you find your feet at George Mason, both socially and intellectually" (George Mason University, 2000). If, in fact, social success is a primary benefit of linked courses, then one would expect an increase in college retention of students who have participated in such links. Finally, Leonard (1996) notes that linked courses not only provide the students participating in them with an increased opportunity for peer collaboration, but that they also provide an opportunity to utilize peer advisors to expose freshmen to successful upperclassmen.

Thus far it appears that much of the data on success rates (GPA in future classes) of students who have participated in linked courses is not statistically significant. However, faculty and students who have participated in 
linked courses tend to report a stronger sense of understanding and appreciation for the material covered (Wilcox \& delMas, 1997).

\section{THE PRESENT STUDY}

\section{The Origin}

As part of an American Assembly of Collegiate Schools of Business (AACSB) reaccredidation review, the College of Business at California State University Chico (CSUC) revised its undergraduate core curriculum. The major change in the curriculum revision was to institute a freshman level activity based learning Introduction to Global Business course. This course is hosted on the College of Business website and can be located at the following web address: http://www.csuchico.edu/acms/BADM_001/. Prior to the change, the college never offered a business course at the freshman level. Students' first and only exposure to business prior to advancing to the upper division had previously been a two- course sequence in managerial and financial accounting.

The goals of the new course were diverse and can be viewed as attempting to satisfy two important objectives: 1) informed affinity to the study of business, and 2) early preparation in the basic knowledge and skills required for the successful study of business. Informed affinity to the study of business was accomplished by providing students the following opportunities:

1. The opportunity to realistically view and understand the role of business in a global society.

2. The opportunity to understand the undergraduate business curriculum and what knowledge and skills they would possess with a degree in business.

3. The opportunity to understand the difference in majoring in one or another business option (e.g., accounting, marketing, production, etc).

4. The opportunity to understand the types of careers associated with different business foci.

5. The opportunity to interact with an upper division business student mentor assigned to each class section.

6. The opportunity to receive credit for the activity involving attending different college of business student organization meetings (i.e., the e-business club, the human resource management association, etc.).

Early preparation in the basic knowledge and skills required for the successful study of business was accomplished by providing students the following opportunities:

1. Activity based opportunities for mastering the set of basic business software applications required by the college in its business coursework (e.g., internet navigation, Excel database, PowerPoint presentation technology, etc.).

2. Activity based opportunities for interacting and completing group based projects and instruction in teamwork.

3. Opportunities for developing oral communication skills in the preparation and delivery of PowerPoint presentations on business or corporate related topics.

4. Opportunities for developing written communication skills in the preparation of numerous task force reports and an individual book report.

5. Opportunities for developing informational competency through guided instruction in the acquisition of electronic and hard copy business and corporate related information (e.g., corporate home pages, Edgar's OnLine, Morningstar, www.NASDAQ.com, etc.).

6. Introductory level exposure to all the functional areas of business within a global context.

To complement the new course, the college decided to cross link half of the sections of the freshman Introduction to Global Business course with two other specially designed freshman courses: English Composition and Small Group Communication. These courses were specifically designed to focus on business related issues. All of the reading, writing and informational competency assignments and activities in the English Composition course were focused on international business. Even the course outline and syllabus were co-designed by a co-author and the professor in the Department of English responsible for the freshman composition course. In like manner, the Small 
Group Communication course focused on workgroups and team leadership within a business context. Each of these other courses fulfilled university general education requirements thus there were no disincentives to students who chose to enroll in the three-course linkage. Enrollment was handled in the following manner. Two sets of 24 students each would enroll in English Composition and Small Group Communication sections and then come together to form one class of forty-eight in the Introduction to Global Business course.

It was anticipated that by creating LCS both the affinity to the study of business and the preparation for the study of business would be enhanced. This new course, its stated objectives, and the enrollment of both LCS and non-LCS formed the basis for the present study.

\section{The Sample}

The sample for the present study consists of two groups - a control group and an experimental group. Students in both groups were asked to sign informed consent documents to give the co-authors permission to track the academic progress of their career so long as they remained business majors at CSUC. The experimental group consisted of 88 (out of 97) students who signed the consent documents and who were enrolled in two sections of the co-author's (a Professor of Management) Introduction to Global Business course in fall 1999. These students were first semester freshman and were part of the linked cohort program. The control group consisted of 49 (out of 120) first semester freshman enrolled in five other sections of Introduction to Global Business in fall 1999. These sections were taught by three faculty members; one was a Professor of Accounting, and the others were full-time Lecturers in Management. Due to catalogue considerations, non-freshmen were also enrolled in these non-cohort linked sections. The 120 (potential) first semester freshman in the control group represented approximately 50\% of the enrollment in these sections. The remainder of the students were sophomores and juniors. Although non-confirmed, it is believed that the higher response rate of students giving informed consent in the co-author's sections was due to student familiarity and trust that the co-author would only use the information for the stated purpose. The author was, for all intent and purpose, unknown to the students in the control group. It is not unexpected therefore that the percent of students giving informed consent to track their academic progress would be lower when compared with the experimental group.

\section{The Hypotheses}

The study investigates two hypotheses comparing the experimental group with the control group:

1. The experimental group will exhibit a higher graduation rate in business than the control group.

2. The experimental group will exhibit higher performance in the study of business (as measured by GPA in the core business courses, both lower and upper division) than the control group.

Since fall 1999, some students have left Chico and are thus not included in the present study. The revised sample sizes are shown in Table 1.

Table 1 Sample Sizes

\begin{tabular}{|c|c|c|c|}
\hline Number of Students & All & Linked & Non-Linked \\
\hline In original study & 137 & 88 & 49 \\
\hline Who have left Chico & 29 & 18 & 11 \\
\hline Used in preliminary analysis & $\underline{108}$ & $\underline{70}$ & $\underline{\underline{38}}$ \\
\hline With no SAT & 8 & 4 & 4 \\
\hline Used in revised analysis with SAT covariates, Hypothesis (1) & $\underline{100}$ & $\underline{66}$ & $\underline{34}$ \\
\hline Who are still Business majors at Chico & $\overline{71}$ & $\overline{49}$ & $\overline{22}$ \\
\hline With no SAT & 4 & 2 & 2 \\
\hline Used in revised analysis with SAT covariates, Hypothesis (2) & $\underline{67}$ & $\underline{47}$ & $\underline{20}$ \\
\hline With no upper division core classes & 3 & $\overline{2}$ & $\overline{1}$ \\
\hline Used in revised analysis with SAT covariates, Hypothesis (2) & $\underline{64}$ & $\underline{45}$ & $\underline{19}$ \\
\hline
\end{tabular}




\section{Results}

Five full years (fall 1999 through summer session 2004) have elapsed since the study began. There are a few students who have taken most of their upper division core courses, but have not yet graduated. It is possible these students might graduate in the future. However, if we assume that the aforementioned students did in fact graduate, a preliminary analysis yields the same conclusions as explained below. Therefore, the authors believe that five years is an appropriate length of time for the study.

Hypothesis (1) There is no statistical evidence that hypothesis (1) is true. For the experimental group, 60.0\% (42/70) of the students have graduated as business majors, whereas 50.0\% (19/38) of students in the control group have graduated as business majors. This difference of $10.0 \%$ is not statistically significant (p-value $=.1584$ ) and so we can not conclude that the graduation rate of students in the experimental group is greater than that of the control group. These results are summarized in Table 2.

Table 2 Statistics For Preliminary Analysis Without SAT Covariates

\begin{tabular}{|l|c|c|c|c|c|}
\hline Characteristic & Linked & $\begin{array}{c}\text { Non- } \\
\text { Linked }\end{array}$ & $\begin{array}{c}\text { Difference: } \\
\text { Link - Non-L }\end{array}$ & p-value & Conclusion \\
\hline$\%$ who have graduated in business & 60.0 & 50.0 & 10.0 & $\begin{array}{c}.1584 \\
(1-\text { tail })\end{array}$ & $\begin{array}{c}\text { No significant } \\
\text { difference }\end{array}$ \\
\hline $\begin{array}{l}\text { Mean GPA per lower division core course, } \\
\text { Business majors only }\end{array}$ & 2.831 & 3.028 & -.197 & $\begin{array}{c}.1861(2- \\
\text { tail) }\end{array}$ & $\begin{array}{c}\text { No significant } \\
\text { difference }\end{array}$ \\
\hline $\begin{array}{l}\text { Mean GPA per upper division core course, } \\
\text { Business majors only }\end{array}$ & 2.709 & 2.829 & -.119 & $\begin{array}{c}.4173(2- \\
\text { tail) }\end{array}$ & $\begin{array}{c}\text { No significant } \\
\text { difference }\end{array}$ \\
\hline $\begin{array}{l}\text { Mean GPA per core course (all core--lower } \\
\text { and upper), Business majors only }\end{array}$ & 2.769 & 2.897 & -.123 & $\begin{array}{c}.3595(2- \\
\text { tail) }\end{array}$ & $\begin{array}{c}\text { No significant } \\
\text { difference }\end{array}$ \\
\hline Mean SAT Math & 527.4 & 516.8 & 10.7 & $\begin{array}{c}.4277(2- \\
\text { tail) }\end{array}$ & $\begin{array}{c}\text { No significant } \\
\text { difference }\end{array}$ \\
\hline Mean SAT Verbal & 491.8 & 495.6 & -3.8 & $\begin{array}{c}.7926(2- \\
\text { tail) }\end{array}$ & $\begin{array}{c}\text { No significant } \\
\text { difference }\end{array}$ \\
\hline Mean SAT Total & 1019.2 & 1012.4 & 6.9 & $\begin{array}{c}.7731 \text { (2- } \\
\text { tail) }\end{array}$ & $\begin{array}{c}\text { No significant } \\
\text { difference }\end{array}$ \\
\hline
\end{tabular}

At this point it is difficult to make any definitive statements about hypotheses (1). First of all, students were not randomly assigned to the two groups, but rather each student chose which section of the course in which to enroll, subject to the constraints of the registration process. So it is possible that students in the experimental group could have some characteristics that could, at least partially, account for any statistical difference between the two groups. Or, these characteristics could mask any difference between the two groups.

One such characteristic might be academic ability of the students, which could be measured by SAT score. We have the SAT scores for 100 of the 108 students involved in this study ( 8 students had not taken the SAT), and we can look at hypothesis (1) from the same point of view as mentioned above, this time taking the SAT scores into consideration. That is, we use the SAT as a covariate, which allows us to compare groups after the data are "adjusted" for differences associated with the SAT scores of the two groups. See Table 1 for the sample sizes.

With regard to the percent of students who after five years have graduated in business, the analysis changes very little when we include the SAT scores. If we use the SAT total as a covariate (adjust the data for differences in SAT scores), we estimate that the percent of students in the cohort linked group (experimental group) who have graduated as business majors is $8.7 \%$ (see Table 3, Regression 1) higher than for students in the non-cohort linked group (control group). This difference is not statistically significant (p-value $=.2020$ ). If we use SAT verbal and math scores as covariates, the estimated difference in percentages drops to 5.9\% (see Table 3, Regression 2), which is not statistically significant $(\mathrm{p}$-value $=.2793$ ). Recall that in the original analysis without the SAT covariates, the percentage difference between the two groups was $10.0 \%$, with a p-value of .1584. We therefore repeat our 
hypothesis (1) conclusion from above: there is no statistical evidence that the graduation rate of students in the experimental group is greater than that of the control group. These results are summarized in Table 3.

Table 3 Regressions For Predicting Graduation In Business

Regression 1, Using SAT Total As A Covariate:

$\operatorname{Grad}=\beta_{0}+\beta_{1}$ Group $+\beta_{2}$ Total, $\mathrm{n}=100, \mathrm{R}^{2}=.028, \mathrm{p}$-value $=.2471$

\begin{tabular}{|c|c|c|c|}
\hline Independent Variable & Coefficient & t-statistic & p-value (2-tail) \\
\hline Intercept & -.199 & & $(1$-tail) .2020 \\
\hline Group & .087 & .838 & .1045 \\
\hline Total & .001 & 1.639 & \\
\hline
\end{tabular}

Regression 2, Using SAT Math And Verbal As Covariates:

Grad $=\beta_{0}+\beta_{1}$ Group $+\beta_{2}$ Math $+\beta_{3}$ Verbal, $n=100, R^{2}=.097, p$-value $=.0203$

\begin{tabular}{|c|c|c|c|}
\hline Independent Variable & Coefficient & t-statistic & p-value (2-tail) \\
\hline Intercept & -.322 & & $(1$-tail) .2793 \\
\hline Group & .059 & .587 & .00285 \\
\hline Math & .003 & 3.066 & .1970 \\
\hline Verbal & -.001 & -1.299 & \\
\hline
\end{tabular}

Grad $1=$ graduated in business; $0=$ did not graduate in business

Group $1=$ linked; $0=$ non-linked

Total SAT total score

Math SAT math score

Verbal SAT verbal score

Hypothesis (2) We do not have statistical evidence that Hypothesis (2) is true. In fact, the experimental group's mean GPA's for completed lower division core business courses, upper division core courses, and all business core courses are lower than the corresponding means for the control group. See Table 2 for these results.

As with hypothesis (1), we can use SAT score as a covariate to try to get a clearer picture. First we eliminate four students in the study who have not taken the SAT. Using SAT total as a covariate, we estimate that the adjusted lower division core GPA per student in the experimental group is .148 (see Table 4, Regression 1) grade points lower than for the control group. Using SAT verbal and math as covariates, the adjusted experimental group lower division core GPA per student is .143 (see Table 4, Regression 2) lower than the control group. As above, we can not conclude that the experimental group lower division core GPA is larger than the control group GPA. These results are shown in Table 4.

Similarly, using the SAT scores as covariates, the results are the same for completed upper division business core and for all business core courses. These results are shown in Tables 5 and 6. 
Table 4 Regressions For Predicting Lower Core GPA

Regression 1, Using SAT Total As A Covariate:

LowGPA $=\beta_{0}+\beta_{1}$ Group $+\beta_{2}$ Total, $n=67, \mathrm{R}^{2}=.222, \mathrm{p}$-value $=.0003$

\begin{tabular}{|c|c|c|c|}
\hline Independent Variable & Coefficient & t-statistic & p-value (2-tail) \\
\hline Intercept & .664 & & $(1$-tail) .8580 \\
\hline Group & -.148 & -1.081 & .0001 \\
\hline Total & .002 & 4.170 & \\
\hline
\end{tabular}

\section{Regression 2, Using SAT Math And Verbal As Covariates:}

LowGPA $=\beta_{0}+\beta_{1}$ Group $+\beta_{2}$ Math $+\beta_{3}$ Verbal, $n=67, R^{2}=.239, p$-value $=.0006$

\begin{tabular}{|c|c|c|c|}
\hline Independent Variable & Coefficient & t-statistic & p-value (2-tail) \\
\hline Intercept & .817 & & $(1-$ tail) .8506 \\
\hline Group & -.143 & -1.048 & .3476 \\
\hline Math & .001 & .946 & .0015 \\
\hline Verbal & .001 & 3.318 & \\
\hline
\end{tabular}

LowGPA GPA per student in lower division core business courses

Group $\quad 1=$ linked; $0=$ non-linked

Total SAT total score

Math SAT math score

Verbal SAT verbal score

Table 5 Regressions For Predicting Upper Core GPA

Regression 1, Using SAT Total As A Covariate:

UpGPA $=\beta_{0}+\beta_{1}$ Group $+\beta_{2}$ Total, $\mathrm{n}=64, \mathrm{R}^{2}=.130, \mathrm{p}$-value $=.0142$

\begin{tabular}{|c|c|c|c|}
\hline Independent Variable & Coefficient & t-statistic & p-value (2-tail) \\
\hline Intercept & 1.050 & & $(1$-tail) .7459 \\
\hline Group & -.097 & -.665 & .0045 \\
\hline Total & .002 & 2.951 & \\
\hline
\end{tabular}

Regression 2, Using SAT Math And Verbal As Covariates:

UpGPA $=\beta_{0}+\beta_{1}$ Group $+\beta_{2}$ Math $+\beta_{3}$ Verbal, $n=64, R^{2}=.153, p$-value $=.0180$

\begin{tabular}{|c|c|c|c|}
\hline Independent Variable & Coefficient & t-statistic & p-value (2-tail) \\
\hline Intercept & 1.290 & & $(1$-tail) .7482 \\
\hline Group & -.097 & -.673 & .7886 \\
\hline Math & .000 & .269 & .0007 \\
\hline Verbal & .003 & 2.721 & \\
\hline
\end{tabular}

UpGPA GPA per student in upper division core business courses

Group $\quad 1=$ linked; $0=$ non-linked

Total SAT total score

Math SAT math score

Verbal SAT verbal score 
Table 6 Regressions For Predicting All Core GPA

Regression 1, Using SAT Total As A Covariate:

AllGPA $=\beta_{0}+\beta_{1}$ Group $+\beta_{2}$ Total, $n=64, \mathrm{R}^{2}=.226, \mathrm{p}$-value $=.0004$

\begin{tabular}{|c|c|c|c|}
\hline Independent Variable & Coefficient & t-statistic & p-value (2-tail) \\
\hline Intercept & .659 & & $(1$-tail) .7382 \\
\hline Group & -.083 & -.642 & .0001 \\
\hline Total & .002 & 4.177 & \\
\hline
\end{tabular}

Regression 2, Using SAT Math And Verbal As Covariates:

AllGPA $=\beta_{0}+\beta_{1}$ Group $+\beta_{2}$ Math $+\beta_{3}$ Verbal, $n=64, R^{2}=.243, p$-value $=.0008$

\begin{tabular}{|c|c|c|c|}
\hline Independent Variable & Coefficient & t-statistic & p-value (2-tail) \\
\hline Intercept & .817 & & $(1-$ tail) .7399 \\
\hline Group & -.083 & -.646 & .3386 \\
\hline Math & .001 & .965 & .0017 \\
\hline Verbal & .003 & 3.292 & \\
\hline
\end{tabular}

AllGPA GPA per student in all core business courses

Group $\quad 1$ = linked; $0=$ non-linked

Total SAT total score

Math SAT math score

Verbal SAT verbal score

If we briefly look at the SAT scores, it is not surprising that inclusion of SAT scores into the analysis does not materially change the results. The SAT scores of the two groups are very similar and certainly are not statistically different (see Table 2). Further, there is no correlation between a student's SAT score and whether or not that student graduates in business.

One possible criticism of using SAT as covariates is that some students in the study did not take the SAT, and these students might somehow be different from those students who did take the SAT. If this is the case, then eliminating these students from the analysis might materially change the results. However, if we repeat the original analysis without covariates, but using only the 100 students who took the SAT, the results are virtually identical to the results using all 108 students. So we are confident that we did not lose significant information when we eliminated those 8 students.

\section{LIMITATIONS}

As mentioned above it is difficult to make any definitive statements about hypotheses (1). First of all, students were not randomly assigned to the two groups, but rather each student chose which section of the course in which to enroll, subject to the constraints of the registration process. So it is possible that students in the experimental group could have some characteristics other than SAT scores that could, at least partially, account for any statistical difference between the two groups. Or, these characteristics could mask any difference between the two groups. For example, it is possible that the students who chose to enroll in the link cohort classes were more certain of their intention to major in business. Further, quite a few students left Chico, and it is impossible to gauge the impact of the cohort linked courses on them.

\section{CONCLUSION}

Overall, there is no statistical evidence that students in the linked cohort classes performed better or had a higher graduation rate in business than those students in the control group. These results are somewhat surprising. 
Previous results, using data from two years prior, gave statistical evidence that a preliminary version of hypothesis (1) was true (Levine and Guy, 2004). That is, at that time, a greater proportion of students in the experimental group were still business majors. Now after an additional two years have passed, whereas the proportion of business graduates in the experimental group is greater than the proportion in the control group, this difference is not statistically significant. It seems that any effect of the linked cohort classes has faded over time. There is no statistical evidence that three linked classes in the freshman year had any lasting effect on either students' performance or graduation in business.

\section{SUGGESTIONS FOR FUTURE RESEARCH}

The experiment describe here is clearly observational, since the students themselves chose which group they were in: the linked (experimental) or the non-linked (control). It would be very instructive to conduct a designed experiment, one in which the students would be randomly assigned to the groups. This would help eliminate bias and strengthen the validity of the conclusions.

It would also be instructive to replicate the experiment in other disciplines, e.g. in an introduction to engineering class, to see if the results here can be generalized to other fields of study.

\section{WORKS CITED}

1. Abercrombie, M.L.J., Anatomy of Judgment, Basic Books, New York, 1960.

2. Dick, R. C., Fundamentals of Communication and First Year Success Seminar: Perspective from a Faculty Member of Linked Courses, Paper presented at the $84^{\text {th }}$ annual meeting of the National Communication Association, New York, November 19-24, 1998.

3. Dunn, P., English 101 and Chemistry 101: Examining Texts Through Different Lenses, Paper presented at the annual meeting of College Composition and Communication, San Diego, California, 1993.

4. Eanes, R. and Tutchings, T., An Evaluation of a College Developmental Reading Program, Paper presented at the annual meeting of the American Reading Forum, Sarasota, Florida, 1990.

5. Fitch, B. and Kirby, A., Students' Assumptions and Professors' Presumptions, College Teaching, Vol. 48, No. 2, p. 47, 2000.

6. Gabelnick, F., MacGregor, J., Matthews, R.S., and Smith, B.L., Learning Communities: Creating Connections Among Students, Faculty, and Disciplines, New Directions for Teaching and Learning, Vol. 41, Jossey-Bass, Inc., San Francisco, 1990

7. Gammill, L., Hansen, C., and Tinkler, S., A Method to Reinforce Basic Skills, Journal of Education for Business, Vol. 67, No. 6, p. 358, 1992.

8. George Mason University, web-site: http://links.gmu.edu/info/faq.html, 2000.

9. Horn, S. K., Ideas in Practice: Extending Collaboration Beyond the Developmental Classroom, Journal of Developmental Education, winter 1997, Vol. 21, No. 2, p. 26, 1997.

10. Kellogg, K., Learning Communities, ERIC Clearinghouse on Higher Education, George Washington University, Washington, DC, 1999.

11. Leonard, J., Learning Communities: Linking the Basic Course to the Greater University Community, Paper presented at the $82^{\text {nd }}$ Annual Meeting of the Speech Communication Association, San Diego, CA, November 23-26, 1996.

12. Levine, M. and Guy, P., Freshman Linked Cohort Classes in the Study of Business: A Comparative Analysis of Performance and Completion of the Lower Division Core, Journal of College Teaching \& Learning, Vol. 1, No. 1, January 2004.

13. Luvass-Briggs, L., Integrating Basic Skills with College Content Instruction, Journal of Developmental \& Remedial Education, Vol. 7, No. 2, p. 31, 1984.

14. O'Connor, T. J. and Ruchala, L. V., A Model for Small-Group Writing Labs in an Accounting Curriculum, Issues in Accounting Education, Vol. 13, No. 1, p. 93, 1998.

15. Smith, B.L., Taking Structure Seriously: The Learning Community Model, Liberal Education, Vol. 77, No. 2, p. 42, 1991.

16. Sorensen, V.P., Bibliographic Instruction in a Developmental Studies Program: A Paired Course Approach, Research Strategies, Vol. 6, No. 4, p. 161, 1988. 
17. Spear, S., Liff, L., Hunt, A., and Jarvis, J., Multicultural literacy: A Context for Composition, Teaching English in the Two Year College, Vol. 17, No. 4, p. 247, 1990.

18. Thompson, C., Assessing the Learning Community: Good News for Speech Communication, Paper presented at the $84^{\text {th }}$ Annual Meeting of the National Communication Association, New York, November 21 24, 1998.

19. Tinto, V. and Goodsell, A., Freshman Interest Groups and the First Year Experience: Constructing Student Communities in a Large University, Paper presented at the annual meeting of the College Reading and Learning Association, Kansas City, Missouri, 1993.

20. Tinto, V., Goodsell-Love, A., and Russo, P., Building Community, Liberal Education, Vol. 79, No. 4, p. 16, 1993.

21. Wilcox, K. J. and delMas, R. C., The 'Package Course' Experience and Developmental Education, Journal of Developmental Education, Vol. 20, No. 3, p. 18, 1997.

22. Wishnet, N., Team Teaching of English Linked to Basic Content Area Courses at Solano Community College, Paper presented at the annual convention of the Community College League of California, Santa Clara, California, 1991. 